\title{
Reoquatia
}

Malavsian Tournal of Society and Space

\section{Pemuliharaan beberapa bangunan bersejarah di Kelantan: Tinjauan ke atas penglibatan komuniti setempat dalam suai guna semula}

\author{
Daeng Haliza Daeng Jamal ${ }^{1} \&$ Zuliskandar Ramli $^{2}$ \\ ${ }^{1}$ Jabatan Pengajian Warisan, Fakulti Teknologi Kreatif dan Warisan, \\ Universiti Malaysia Kelantan \\ ${ }^{2}$ Institut Alam dan Tamadun Melayu, \\ Universiti Kebangsaan Malaysia
}

Correspondence: Daeng Haliza Daeng Jamal (email: haliza.j@umk.edu.my)

Received: 31 March 2021; Accepted: 07 May 2021; Published: 29 May 2021

\begin{abstract}
Abstrak
Bangunan bersejarah merupakan salah satu nilai kebudayaan yang melambangkan identiti sesebuah bangsa. Usaha untuk memulihara dan memelihara bangunan bersejarah daripada ancaman kemusnahan perlu dilakukan secara komprehensif dan komited oleh semua pihak termasuk komuniti setempat. Hal ini kerana komuniti setempat merupakan pihak yang paling hampir untuk dirujuk dalam usaha melindungi aset warisan daripada ancaman kepupusan. Komuniti setempat juga adalah kelompok yang akan menerima manfaat hasil usaha pemuliharaan dan pemeliharaan warisan. Oleh itu, kajian ini bertujuan membincangkan penglibatan komuniti setempat dalam usaha memulihara dan memelihara bangunan bersejarah di kawasan mereka khususnya menerusi pendekatan suai guna semula. Kajian ini menggunakan kaedah kualitatif dan data dianalisis dengan pendekatan analisis tematik. Kerangka Tangga Penyertaan (Ladder of Participation) yang dikemukakan oleh Arnstein dijadikan panduan dalam menganalisis penglibatan komuniti bagi kajian ini. Hasil tinjauan di lapangan mendapati, komuniti setempat di kedua-dua jajahan ini telah menunjukkan komitmen yang tinggi dalam memulihara dan memelihara bangunan bersejarah dengan menggunakannya semula. Masjid Lama Kedai Mulong telah dibina oleh penduduk kampung dengan menggunakan pendekatan suai guna semula. Komuniti Peranakan Cina di Tanah Merah juga didapati mempunyai kesedaran dan komitmen untuk melindungi rumah tradisional mereka daripada ancaman kemusnahan. Hal ini dibuktikan dengan wujudnya Galeri Peranakan Cina Kelantan hasil penyesuaigunaan semula salah satu rumah tradisional komuniti ini. Secara tidak langsung kajian ini membuktikan selain pihak kerajaan, komuniti setempat turut membantu dan proaktif dalam melestarikan warisan setempat. Pemuliharaan aset warisan yang turut disertai komuniti setempat dilihat memberi impak positif kepada perkembangan ekonomi dan sosial setempat. Komuniti setempat turut berpotensi memperoleh manfaat daripada pelancongan warisan yang wujud di kawasan mereka.
\end{abstract}

Kata kunci: Bangunan bersejarah, Kelantan, komuniti setempat, pemuliharaan, penyesuaigunaan semula, pelestarian warisan 


\title{
Conservation of several historic buildings in Kelantan: A survey on involvements of the local community in adaptive reuse
}

\begin{abstract}
A historic building is an integral part of cultural values that may symbolise a national identity. It is thus suggested that efforts of conservation and preservation should be collectively shouldered including the local community to prevent destruction. This study aims at explore the involvements of the local communities in their efforts of conserving and preserving the several historic buildings in Kelantan through the adaptive reuse approach. The study will use a qualitative method and data analysis with a thematic analysis approach. The Ladder of Participation framework introduced by Arnstein was used to analyse the involvement of local communities in conserving the historic buildings. Findings of field observation found that local communities in these two districts have shown their high commitments in the conservation and preservation of historic buildings using the adaptive reuse approach. Kedai Lama Mulong Mosque built by villagers using adaptive reuse approach. Peranakan Chinese community in Tanah Merah also found have an awareness and commitments to protect their traditional house from the threat of destruction. This proved by the existence of Galeri Peranakan Cina Kelantan which was built by reusing their traditional house. Indirectly, this research proves that, apart from the state government, the local communities with their proactiveness and helps, may contribute significantly in efforts of heritage sustainability. Conservation of heritage asset that also involving the local community seen has results a positive impact to economic growth and social. The local community also has the potential to gain benefit from heritage tourism that exists in their area.
\end{abstract}

Keywords: Historic building, Kelantan, local community, conservation, adaptive reuse, heritage sustainability

\section{Pengenalan}

Warisan kebudayaan di Malaysia dilindungi oleh beberapa dokumen perundangan terutamanya Akta Warisan Kebangsaan (Akta 645) yang diperkenalkan pada tahun 2005. Namun, dokumen perundangan ini dilihat masih belum mampu memulihara produk warisan secara komprehensif sekiranya tidak mendapat kerjasama dan penglibatan daripada komuniti setempat. Hal ini kerana, komuniti setempat adalah kelompok paling hampir dengan produk warisan, sama ada warisan berbentuk ketara mahupun tidak ketara. Komuniti setempat merujuk kepada kelompok yang memiliki kecenderungan yang sama dan komitmen untuk mencapai objektif yang dibentuk Bersama. Komuniti setempat juga adalah kelompok yang berpeluang merasai dan menyaksikan perubahan yang berlaku ke atas produk-produk warisan di kawasan mereka. Maka, pengalaman merasai dan menyaksikan perubahan-perubahan ini menjadikan komuniti setempat sebagai pusat rujukan dan 'orang pakar' yang relevan dalam usaha memulihara dan memelihara produk-produk warisan di kawasan tersebut. Hal ini sejajar dengan sifat warisan itu sendiri yang berkait rapat dengan kebudayaan sesebuah masyarakat. 
Jika dilihat daripada perspektif pengurusan warisan, penglibatan komuniti setempat berpotensi merealisasikan objektif kerajaan untuk melindungi produk warisan. Hal ini seperti yang dihujahkan Mohd Jaki (2014) \& Esther (2011), penglibatan komuniti setempat dalam pemuliharaan dan pemeliharaan produk warisan termasuk bangunan bersejarah dapat dilaksanakan secara komprehensif melalui pendekatan atas-bawah (up-bottom approach) dan bawah-atas (bottom-up approach). Dari sudut lain pula, komuniti setempat adalah entiti penting untuk dilibatkan dalam projek pemuliharaan dan pemeliharaan sesebuah kawasan bersejarah bagi kesan jangka masa panjang. Hal ini sejajar dengan hujahan Teuku Afrizal \& Abdul Rahman Embong (2013) yang menyatakan rasa kepemilikan atau perasaan sepunya perlu ada dalam kalangan komuniti yang berkongsi kepentingan yang sama bagi menjamin kelangsungan dan kesejahteraan mereka.

Pemahaman komprehensif terhadap persekitaran warisan dalam kalangan komuniti setempat akan mendorong ahli komuniti menghargai produk-produk warisan yang terdapat di persekitaran mereka (Plested et al., 2006 \& Heritage England, 2013). Penglibatan komuniti setempat didapati memainkan peranan penting dalam proses pemuliharaan bangunan bersejarah di kawasan mereka. Hal ini seperti yang ditegaskan oleh Tosun (2006) yang menyatakan penglibatan komuniti setempat adalah tindakan kesukarelaan ahli dalam komuniti yang saling bekerjasama dan bertanggungjawab dalam mempertahankan nilai-nilai kemasyarakatannya. Penglibatan komuniti setempat dalam pengekalan warisan di kawasan mereka bergantung kepada dasar yang ditetapkan pihak berwajib yang juga merujuk dan peka dengan penerimaan komuniti setempat (Mohamad Khairul Anuar et al. 2021). Hal ini kerana, penglibatan mereka ini pada akhirnya akan menentukan proses sosial mereka pada masa hadapan selain memenuhi kehendak komuniti.

Menurut Abdullah Hassan (2009) perasaan kekitaan dalam sesebuah bangsa lahir daripada perasaan sepunya atau dapat ditandai dengan ciri-ciri sepunya seperti sama leluhurnya, bertutur bahasa yang sama, mengamalkan kebudayaan yang sama, berpegang kepada agama yang satu, dan bermastautin dalam geografi yang sama. Dalam konteks negara Malaysia yang terdiri daripada pelbagai bangsa dan agama, ciri kebudayaannya adalah bersifat rencam dan unik. Kebudayaan yang diwarisi turun temurun ini menggambarkan kekebalan, keutuhan dan keperibadian yang tinggi dalam diri setiap individu sesebuah bangsa itu. Justeru, warisan budaya yang diwarisi ini masih lagi dipertahankan dalam kalangan masyarakat majmuk Malaysia sehingga ke hari ini.

Warisan budaya termasuk juga warisan budaya ketara seperti bangunan bersejarah wajar dipulihara kerana terdapat nilai dan kepentingan sejarah, warisan dan berpotensi menjana ekonomi setempat. Nilai dan kepentingan itu pula harus memiliki kriteria seperti tarikan reka bentuk seni bina, teknologi dan teknik pembinaan yang unik dan cantik, seni pertukangan yang halus dan sarat dengan falsafah yang terdapat pada bangunan bersejarah (Sabzali Khan et al., 2011). Bangunan bersejarah juga merupakan warisan kebudayaan ketara yang membuktikan kemajuan teknologi, pemikiran dan kegemilangan tamadun ketika pembinaannya. Hal ini sejajar dengan A. Ghafar (2000) yang mendefinisikan bangunan bersejarah sebagai bangunan yang mempunyai unsur sejarah, budaya dan nilai seni bina yang unik. Pengertian bangunan bersejarah dapat memberi gambaran tentang kepelbagaian reka bentuk dan seni bina yang mempunyai nilainilai warisan dan keindahan yang tinggi, menjadikan ciri-ciri setiap binaan bangunan bersejarah tersebut berbeza antara satu sama lain.

Oleh itu, bangunan bersejarah perlu dipulihara dan dipelihara agar nilai-nilai warisannya dapat dilihat generasi akan datang. Antara pendekatan terbaik untuk memanjangkan jangka hayat 
bangunan bersejarah adalah dengan menggunakan atau menyesuaigunakannya semula. Penyesuaigunaan semula bangunan bersejarah dalam bahasa yang mudah difahami adalah mengubah fungsi bangunan kepada suatu fungsi baharu bagi memenuhi keperluan semasa. Hal ini seperti yang ditakrifkan Syed Zainol Abidin Idid (1995) mengenai penyesuaigunaan bermaksud mengubahsuai sesuatu selaras dengan jenis kegunaan seperti yang dicadangkan. Manakala Lilawati Ab Wahab et al. (2008) pula menghuraikan penyesuaigunaan semula bangunan bersejarah sebagai pendekatan mengubah fungsi bangunan berkenaan kepada satu fungsi baharu dan kebiasaannya melibatkan sedikit pengubahsuaian bagi memenuhi keperluan fungsi baharu bangunan berkenaan. Pengertian yang sama turut diutarakan oleh Douglas (2006) yang mendefinisikan penyesuaigunaan semula sebagai “... any work to a building over and above maintenance to change its capacity, function or performance, in other words, any intervention to adjust, reuse or upgrade a building to suit new conditions or requirements".

Berdasarkan pengertian-pengertian ini, dapat disimpulkan penyesuaigunaan semula bangunan bersejarah bertujuan untuk memanjangkan jangka hayat bangunan berkenaan dengan mengubah fungsinya kepada suatu fungsi baharu bagi kegunaan semasa. Oleh itu, dalam usaha menyelamatkan bangunan bersejarah daripada ancaman kemusnahan, komuniti setempat perlu dilibatkan bersama kerana komuniti setempat adalah kelompok yang paling hampir dan berpengalaman dengan perubahan sesuatu aset warisan dalam lingkungan mereka. Hal ini menjadikan komuniti setempat adalah kelompok yang relevan untuk dijadikan rujukan dalam proses pemuliharaan dan pemeliharaan sesebuah bangunan bersejarah.

\section{Sorotan literatur}

Tinjauan kajian lepas mendapati, kajian mengenai penglibatan komuniti setempat dalam pemuliharaan dan pemeliharaan bangunan bersejarah termasuk menerusi pendekatan menyesuaigunakannya semula telah banyak dilakukan oleh para sarjana. Walau bagaimanapun, kajian mengenai penglibatan komuniti setempat dalam penyesuaigunaan semula bangunan bersejarah di Kelantan di dapati masih kurang dilakukan. Justeru, kajian ini bertujuan membincangkan penglibatan komuniti setempat dalam pemuliharaan dua (2) buah bangunan bersejarah di Kelantan menerusi pendekatan penyesuaigunaan semula.

Komuniti setempat merujuk kepada sekumpulan manusia yang berkongsi budaya dan peraturan yang sama seperti menetap di kawasan yang sama, berinteraksi antara satu sama lain serta budaya. Menurut Abdullah et al. (2017) komuniti setempat merupakan kumpulan dinamik yang sering berubah dan berkembang secara evolusi yang terhasil daripada bentuk komuniti primitif sehinggalah kepada bentuk komuniti maya. Haliza (2010) pula menghuraikan penglibatan komuniti setempat secara langsung diperlukan dalam memastikan pembangunan mampan di kawasan mereka. Hal ini turut disokong Rina Ilyana (2007) yang menghuraikan penglibatan komuniti setempat dalam pembangunan fizikal dilihat berpotensi memelihara keunikan atau warisan di kawasan mereka. Hujahan ini membuktikan penglibatan komuniti dalam pemuliharaan dan pemeliharaan sesebuah aset warisan adalah saling berkaitan.

Kajian Solihah Mustafa et al. (2015) dalam artikel bertajuk Pengurusan bandar warisan UNESCO dan penglibatan komuniti tempatan: Kajian kes di Georgetown, Pulau Pinang pula menghuraikan tahap penglibatan komuniti dalam pemuliharaan warisan di Georgetown, Pulau Pinang. Dapatan kajian ini dilihat berpotensi membantu pihak berkuasa misalnya Jabatan Warisan Negara (JWN) dalam meneliti semula bentuk dan tahap penglibatan komuniti setempat 
dalam pemuliharaan warisan. Kajian ini menggunakan kaedah pemerhatian dan temu bual seramai 27 orang responden yang terdiri daripada komuniti setempat. Hasil kajian ini mendapati penglibatan komuniti setempat dalam pemuliharaan warisan masih lagi berada di tahap rendah. Ini dibuktikan dengan hanya $20.6 \%$ responden terlibat dalam aktiviti pemuliharaan warisan di kawasan mereka. Kajian ini juga menemukan pihak berwajib telah banyak menjalankan projek pemuliharaan di Georgetown, namun projek ini hanya menumpukan pemilik bangunan atau rumah, ahli akademik, kontraktor dan pihak pengurusan. Pihak berwajib juga memberikan komitmen yang tinggi dalam pemuliharaan warisan daripada segi pengurusan, pemantauan dan pendanaan bagi memastikan kelestarian warisan di Georgetown tidak terganggu. Komuniti setempat juga didapati berminat untuk melibatkan diri dalam pemuliharaan warisan di kawasan mereka, namun tidak dilibatkan secara langsung dan hanya bersifat penglibatan secara tidak ketara.

Selain itu, penglibatan komuniti setempat dalam pemuliharaan bangunan warisan juga didapati berpotensi melestarikan warisan ketara tersebut dan dalam masa yang sama menyumbang kepada perkembangan ekonomi setempat menerusi pelancongan warisan. Kajian Bullen \& Love (2011) misalnya, meneliti keberkesanan pendekatan penyesuaigunaan semula bangunan bersejarah dalam persekitaran bandar yang mampan. Perbincangan ini meliputi aspek ekonomi, budaya dan kepentingan sosial bagi komuniti bandar di Australia. Responden kajian mereka ini ialah arkitek, pemaju dan pengurus bangunan bersejarah melibatkan pandangan dan pengalaman pihak berkenaan dalam kerja-kerja menyesuaigunakan semula beberapa bangunan bersejarah di Australia. Hasil kajian ini mendapati walaupun pendekatan menyesuaigunakan semula bangunan bersejarah ini banyak memberikan kesan positif terutamanya daripada segi memulihara dan memelihara nilai warisan serta kestabilan alam semula jadi tetapi pendekatan ini juga menimbulkan kesan negatif. Selain itu, pendekatan penyesuaigunaan semula bangunan bersejarah turut memberi impak baik terhadap komuniti, mewujudkan rasa sepunya dan kelangsungan sosial komuniti. Dalam masa yang sama, timbul juga konflik dan dilema antara menyelamatkan nilai warisan dengan menjayakan agenda rupa bentuk bandar yang mampan.

Mohamad Khairul Anuar et al. (2021) pula menulis tentang kelestarian bandar warisan di Malaysia daripada perspektif pembinaan kerangka konstruk baharu. Kajian ini telah membina satu kerangka pembinaan konstruk kelestarian bandar warisan di Malaysia dengan memperkenalkan konstruk baharu bagi tujuan mengukur indeks kelestarian bandar warisan di Malaysia. Hasil analisis dokumen, kajian ini menemukan tiga (3) konstruk yang telah digunakan di Malaysia dan dibina oleh Brundland Report (1987) iaitu kemakmuran ekonomi, kesejahteraan sosial dan kesejahteraan alam sekitar. Selain itu, hasil analisis dokumen juga telah memperkenalkan dua (2) konstruk baharu iaitu warisan budaya dan peranan komuniti serta kerajaan. Maka, kajian ini telah berjaya memperkenalkan kerangka pembinaan konstruk kelestarian bandar warisan di Malaysia yang mengandungi kelima-lima konstruk ini. Kerangka pembinaan kontstruk kelestarian bandar warisan ini adalah penting dalam pembangunan sesebuah bandar termasuklah bandar warisan seperti yang ditekankan Sustainable Development Goals (SDGs) melalui Matlamat ke-11 iaitu pembentukan bandar dan komuniti lestari. Kajian ini menghuraikan komuniti setempat perlu dilibatkan secara proaktif dengan melihat kesediaan generasi muda menerima aset-aset warisan budaya di kawasan mereka. Penglibatan aktif mereka dalam aktiviti berunsurkan warisan seperti seni persembahan tradisional, seni mempertahankan diri tradisional dan lain-lain warisan memperlihatkan kesediaan mereka dalam menerima warisan budaya. Selain itu, peranan ahli komuniti yang terlibat sama dalam aktiviti kebudayaan dan warisan juga menyumbang kepada kelestarian warisan di sesebuah kawasan. Dalam usaha 
mencapai kelestarian bandar warisan di Malaysia, maka kelima-lima konstruk dalam kerangka ini perlu dikaitkan antara satu sama lain bagi menjamin kesejahteraan komuniti setempat.

Manakala kajian Conejos, Langston \& Smith (2011) pula mendapati pendekatan penyesuaigunaan semula bangunan bersejarah berdaya maju sebagai kaedah yang menggabungkan reka bentuk mampan dengan prinsip konservasi yang mempunyai nilai sejarah yang tinggi. Menyedari perlunya keseimbangan antara pembangunan mampan yang mesra alam semula jadi untuk kebaikan masa akan datang, maka pengkaji menekankan keberkesanan pendekatan penyesuaigunaan semula bangunan bersejarah dalam pelbagai aspek. Hasil penyelidikan mereka mendapati pendekatan penyesuaigunaan semula bangunan bersejarah berpotensi mengurangkan penggunaan tenaga dan air, menjamin kesejahteraan sosial dengan menggiatkan semula bangunan-bangunan bersejarah dan persekitaran yang bernafas baharu. Kajian ini juga telah berjaya menghasilkan sebuah model dikenali sebagai adapSTAR sebagai menanda aras bangunan bersejarah yang telah disuai guna semula. Model ini digunakan pada bangunan bersejarah yang telah disuai guna semula dengan memberi penarafan yang sama seperti sistem penarafan bangunan mesra alam sekitar (green building rating system). Faktor fizikal dan fungsi bangunan, ekonomi, teknologi, sosial, perundangan dan politik diambil kira sebagai kriteria penarafan bangunan bersejarah dalam model ini. Kajian ini juga merumuskan komuniti perlu dilibatkan dalam penyesuaigunaan semula agar manfaat daripada pendekatan ini dapat dirasai dengan optimum.

Shen \& Langston (2010) dalam artikel bertajuk Adaptive reuse potential: an examination of differences between urban and non-urban projects pula mengupas tentang potensi amalan suai guna semula bangunan bersejarah di Hong Kong dan Australia. Artikel ini adalah kajian lanjutan berkenaan potensi penyesuaigunaan semua (Adaptive Reuse Potential, ARP). Kajian ini berbentuk kajian perbandingan. Menerusi kaedah pemerhatian, sebanyak 64 bangunan yang telah disuai guna semula daripada seluruh dunia dijadikan kayu pengukur bagi kajian ini. Model skor ARP digunakan dalam menganalisis bangunan yang telah disuai guna semula tersebut. Hasil kajian ini mendapati sebanyak 12 bangunan suai guna semula di Hong Kong mencatatkan skor rendah berbanding 12 bangunan di kawasan pedalaman yang telah disuaigunakan semula di Australia. Hasil kajian ini juga mendapati bahawa kesedaran pendekatan penyesuaigunaan semula di Hong Kong masih rendah dan menyebabkan banyak peluang berharga seperti ekonomi, sosial dan persekitaran tidak dapat digunakan dengan baik dan optimum. Dalam masa yang sama kajian ini juga dilihat berjaya membantu golongan pembuat keputusan dalam mengaplikasikan dengan betul pendekatan ini.

Kajian mengenai keberkesanan penyesuaigunaan semula bangunan bersejarah di Malaysia juga telah dilakukan beberapa orang sarjana tempatan. Saiful Fazli Ramli (2011) misalnya dalam kajian peringkat sarjananya bertajuk Adaptive Reuse for Historical Buildings in Malaysia. A Case Study: Bukit Kepong Police Station, Malaysia membincangkan tentang penyesuaigunaan semula salah satu bangunan bersejarah terpenting dalam sejarah kemerdekaan negara iaitu Balai Polis Bukit Kepong, Muar, Johor. Di awal penulisannya mengupas tentang definisi penyesuaigunaan semula dan bangunan bersejarah dan seterusnya meneliti kepentingan memelihara bangunan bersejarah untuk generasi akan datang. Bagi menyokong kajiannya, beberapa contoh bangunan bersejarah di Malaysia dan United Kingdom yang telah disuai guna dijadikan sumber kajian lepasnya. Kajiannya memfokuskan keberkesanan konsep penyesuaigunaan semula dan meneliti sejauh mana aplikasinya dalam memelihara bangunan bersejarah dengan pendekatan menukar fungsinya. Kajiannya mendapati bangunan Balai Polis 
Bukit Kepong, Muar, Johor yang telah disuaigunakan kepada muzium berpotensi menyumbang ke arah ekonomi dan sosial serta sangat bermanfaat untuk generasi akan datang.

Manakala, kajian Kamarul Syahril Kamal et al. (2007) pula mengkhusus kepada kerja penyesuaigunaan semula bangunan kolonial di Ipoh menerusi artikel yang membincangkan tentang kepentingan pemuliharaan warisan di bandar Ipoh dan meneliti kecacatan pada bangunan bersejarah terbabit. Kajian ini juga membincangkan tentang hasil penemuan kajian yang mendapati bahawa ada di antara bangunan warisan ini tidak dipulihara dengan baik dan ada yang telah dirobohkan serta diabaikan. Selain itu, penulisan ini turut mengetengahkan kecacatan dan kerosakan pada bangunan warisan serta kepentingan pewartaannya.

Berdasarkan kajian-kajian penyelidik terdahulu dapat disimpulkan komuniti setempat yang terlibat sama dalam proses pemuliharaan bangunan bersejarah khususnya menerusi pendekatan penyesuaigunaan semula telah memberikan pelbagai impak positif kepada mereka seperti pembangunan infrastruktur, peluang pekerjaan dan menjamin kemapanan alam sekitar kerana dapat mengurangkan potensi pembangunan semula. Bagi meninjau penglibatan komuniti dalam pemuliharaan bangunan bersejarah yang diteliti, kajian ini menggunakan kerangka Ladder of participation yang diasaskan oleh Arnstein (1969) yang telah memperkenalkan lapan (8) peringkat penyertaan dari pasif (non-participatory) ke aktif (degree of citizen). Penyertaan komuniti setempat akan berubah dari pasif ke aktif apabila mereka mempunyai tahap penyertaan yang berbeza sehingga mencapai tahap tertinggi iaitu mengawal masyarakatnya (citizen control) untuk mencapai sesuatu objektif. Perbincangan ini dijelaskan seperti rajah berikut:

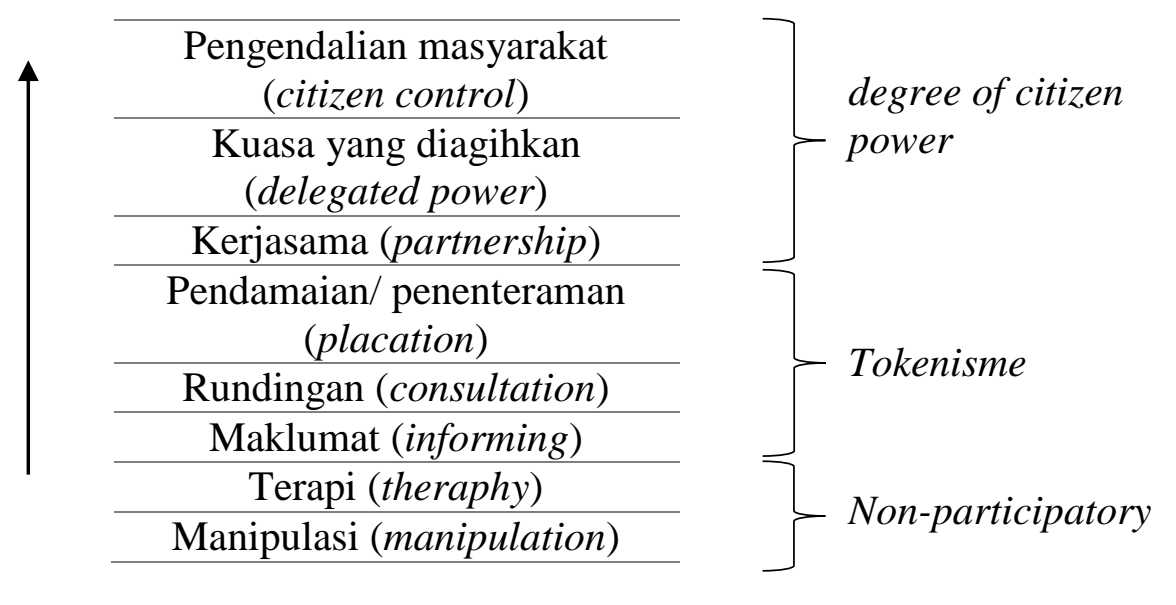

Sumber: Ladder of participation oleh Arnstein (1969)

Rajah 1. Kerangka tangga penyertaan masyarakat (Ladder of participation) oleh Arnstein (1969).

\section{Kaedah dan skop kajian}

Kaedah kajian yang digunakan untuk mengumpul data ialah kaedah kualitatif iaitu pemerhatian dan kajian kepustakaan dengan menganalisis sumber-sumber sekunder berbentuk buku, artikel dan kajian sarjana berbentuk penyelidikan bahan tidak terbit. Data kualitatif dianalisis dengan menggunakan kaedah analisis kandungan yang dipecahkan kepada beberapa tema dengan menggunakan pendekatan tematik. Sumber sekunder yang dirujuk merangkumi artikel berbentuk digital dari pangkalan data Web of Science, Google Scholar, Scopus dan Science Direct. Selain 
itu, laman web rasmi institusi kerajaan seperti Jabatan Warisan Negara, Perbadanan Muzium Negeri Kelantan dan badan bukan kerajaan (NGO) iaitu Persatuan Peranakan Cina Kelantan (PPCK) juga dirujuk. Selain itu, buku-buku berkaitan pemuliharaan, bangunan bersejarah di Kelantan dan pelestarian warisan turut dirujuk. Kesemua sumber sekunder ini dipilih berdasarkan kata kunci yang dibentuk seperti komuniti setempat, penyesuaigunaan semula, bangunan bersejarah di Kelantan dan pemuliharaan bangunan bersejarah. Teknik analisis kandungan dokumen digunakan dengan membaca keseluruhan teks secara berulang bagi mentafsir semula, membuat interpretasi dan mengeluarkan idea berkaitan perbincangan utama, konsep atau perbincangan susastera bagi mencapai tafsiran yang memuaskan. Setelah itu, satu kesimpulan hasil analisis dokumen dibuat bagi memastikan analisis yang dilakukan berdasarkan kata kunci bertepatan dengan kehendak kajian.

Pemerhatian tidak turut serta atau direct-observation juga dilakukan di kawasan kajian iaitu Tanah Merah dan Mulong, Kota Bharu. Bangunan bersejarah yang diteliti di Tanah Merah ialah Galeri Peranakan Cina Kelantan yang terletak di Tanah Merah, dan Masjid Ar-Rahman atau juga dikenali sebagai Masjid Lama Kedai Mulong, di Mulong. Rasional pemilihan keduakedua bangunan bersejarah ini adalah kerana bangunan-bangunan ini adalah antara projek penyesuaigunaan semula yang telah membabitkan komuniti setempat secara langsung. Perkaraperkara di lapangan seperti aktiviti komuniti setempat, fungsi baharu bangunan bersejarah dan refleksi pengkaji dicatatkan dalam nota lapangan dan dibantu dengan alatan kajian seperti kamera. Pemerhatian dianalisis dengan menggunakan tema-tema yang telah dibentuk seperti penglibatan komuniti setempat, pemuliharaan, penyesuaigunaan semula dan impaknya.

\section{Dapatan kajian dan perbincangan}

Kajian ini menumpukan kepada penglibatan komuniti setempat dalam penyesuaigunaan semula bangunan bersejarah di Mulong, Kota Bharu dan Tanah Merah. Bangunan bersejarah yang dikaji ialah Masjid Lama Kedai Mulong, Kota Bharu dan Galeri Peranakan Cina Kelantan, Tanah Merah. Penglibatan komuniti setempat dianalisis menggunakan kerangka Tangga Penyertaan

Penglibatan komuniti setempat dalam penyesuaigunaan semula bangunan bersejarah di Masjid Lama Kedai Mulong

Masjid yang terletak di Kampung Kedai Mulong ini merupakan masjid kayu yang pada asalnya terletak di bandar Kota Bharu, Kelantan. Struktur binaan masjid ini telah dibina sekitar tahun 1900 ketika zaman pemerintahan Sultan Muhamad IV. Masjid ini juga dikenali sebagai Masjid Ar Rahman. Pada asalnya, bangunan masjid ini merupakan sebuah balairung seri milik Raja Dewa yang merupakan gelaran kepada Tuan Zainal Abidin iaitu salah seorang putera kepada Sultan Muhammad III dan saudara kandung Sultan Muhammmad IV. Lokasi asal bangunan ini adalah di kawasan perkampungan raja di Kota Bharu yang terletak berhampiran dengan Istana Jahar, Istana Balai Besar dan Masjid Muhammadi. Atas faktor tertentu, Raja Dewa tidak lagi menggunakan istana ini dan terbiar sehingga selepas Perang Dunia Kedua (Jabatan Warisan Negara 2009).

Penglibatan komuniti setempat dalam usaha untuk melindungi bangunan bersejarah daripada ancaman kepupusan dapat dilihat menerusi tindakan penduduk kampung Kedai Mulong yang telah sepakat membeli bangunan ini untuk dibawa ke tempat mereka untuk dijadikan 
sebagai masjid. Penduduk kampung telah membeli struktur dan komponen bangunan ini dengan harga RM1000 pada tahun 1958. Pada ketika itu, penduduk kampung Kedai Mulong tidak mempunyai masjid. Tindakan penduduk kampung untuk mengubah fungsi balairung seri kepada masjid membuktikan perubahan tahap penyertaan dari pasif ke aktif menerusi kerangka Tangga Penyertaan Masyarakat (Arnstein, 1969). Hal ini dapat dilihat apabila kerja-kerja mengubahsuai fungsi balairung ini dilakukan secara gotong royong oleh komuniti setempat untuk diubah kepada masjid. Ubah suai ini juga mendapat bimbingan dan kerjasama dari JWN yang turut membantu penduduk kampung daripada segi teknikal, pemantauan dan pendanaan. Pemerhatian di lapangan mendapati, pada masa kini masjid ini tidak lagi digunakan untuk solat Jumaat kerana kekangan saiznya yang tidak mencukupi untuk menampung bilangan jemaah. Penduduk kampung akan mengerjakan solat Jumaat di masjid baharu yang terletak berhampiran Masjid ArRahman ini. Meskipun begitu masjid lama ini masih terus dikunjungi oleh penduduk sekitar bagi menunaikan solat lima waktu berjemaah dan menjalankan aktiviti keagamaan lain (Rajah 1).

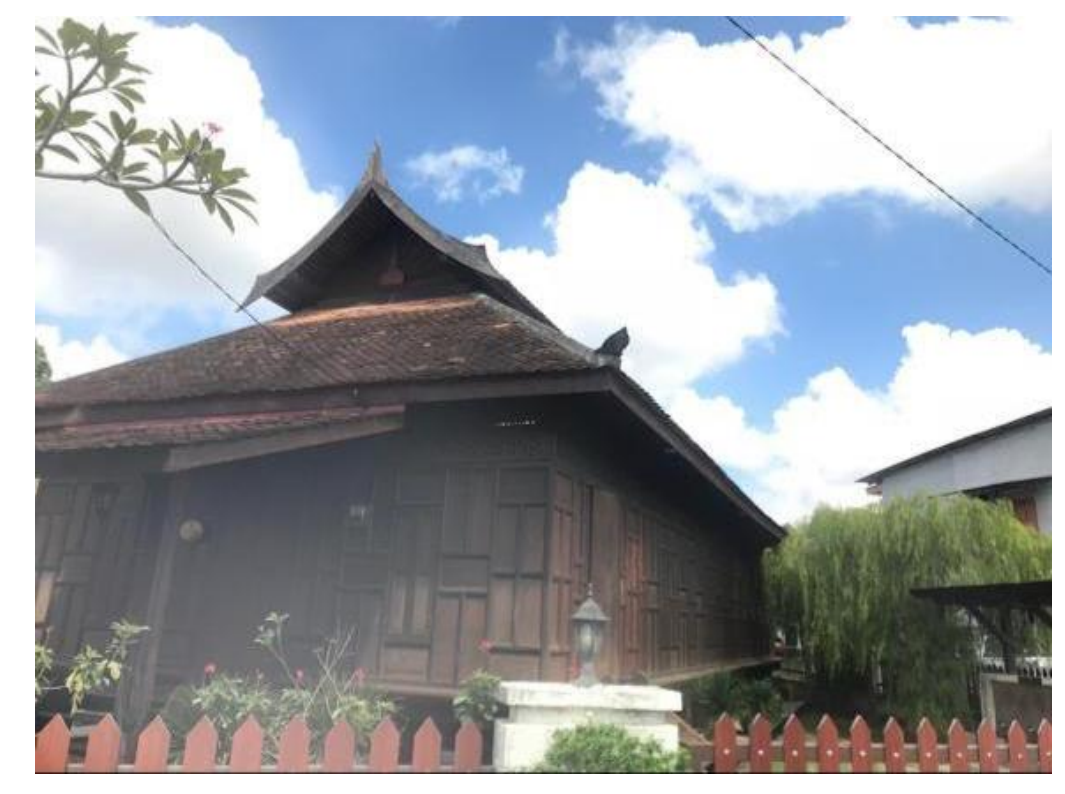

Rajah 1. Masjid Lama Kedai Mulong pada masa kini.

Usaha ini telah membuktikan komuniti setempat telah mempunyai kesedaran dan komitmen dalam melestarikan warisan. Hasil kajian menemukan, penduduk Kampung Kedai Mulong secara sukarela melibatkan diri dalam melindungi warisan dengan membuat penyesuaigunaan semula ke atas struktur asal balairung seri tersebut untuk dijadikan masjid bagi kegunaan harian. Walaupun tidak mempunyai sistem rekod dan pendokumentasian yang sistematik, komuniti setempat telah dilibatkan bersama oleh pihak berkuasa seperti JWN yang telah merujuk penduduk kampung sepanjang proses pemuliharaan dilakukan (Jabatan Warisan Negara 2009). Pada peringkat ini, tahap penyertaan mereka adalah pada tahap tokenisme kerana mereka berupaya memberi maklumat (informing) dan terlibat dalam khidmat rundingan (consultation) serta placation. Justeru, kerjasama ini dilihat banyak membantu komuniti setempat dalam memperkasakan kesedaran untuk memulihara dan memelihara aset warisan. Dalam erti kata lain, kerjasama dengan agensi bertanggungjawab didapati membantu komuniti setempat dalam mewujudkan sistem rekod dan dokumentasi bagi Masjid Lama Kedai Mulong. Secara tidak langsung penglibatan dan keseriusan komuniti setempat dalam pemuliharaan masjid ini 
dapat memberi manfaat dalam jangka masa panjang kerana pendokumentasian yang ada dapat dijadikan sumber rujukan pada generasi akan datang. Kini, masjid ini merupakan salah satu tarikan pelancong di Kelantan dan juga sering menjadi pusat rujukan kumpulan profesional dan pelajar-pelajar dalam bidang seni bina dan warisan bagi mengkaji keunikan, estetika dan falsafah seni binanya. Dalam masa yang sama, komuniti setempat juga menerima kemudahan jaringan pengangkutan dan kemudahan lain di kawasan mereka.

\section{Penglibatan komuniti setempat dalam penyesuaigunaan semula Galeri Peranakan Cina Kelantan}

Penglibatan komuniti dalam pemuliharaan bangunan bersejarah di Tanah Merah diteliti dengan mengambil sampel salah sebuah rumah tradisional Peranakan Cina Kelantan yang ditukar fungsinya kepada galeri. Komuniti setempat yang terlibat terdiri daripada penduduk kampung dan Persatuan Peranakan Cina Kelantan (PPCK). PPCK telah ditubuhkan pada 15 Februari 1989 oleh komuniti Peranakan Cina di beberapa kawasan sekitar lembah Sungai Kelantan. Tujuannya bagi memastikan kewujudan komuniti ini bersatu padu dan kekal relevan dengan arus pembangunan negara di samping mengekalkan budaya dan tradisinya. Pada asalnya, persatuan ini beroperasi di Dewan Orang Ramai Wat Pracacinaram, Wakaf Bharu, Kelantan. Namun, pejabat operasi persatuan ini telah berpindah ke Pasir Parit, Tanah Merah, Kelantan. Sehingga kini, PPCK telah mencatatkan keahlian seramai 3,000 orang di seluruh Kelantan termasuk Peranakan Cina yang menetap di luar Kelantan. Bagi menggalakkan ahli PPCK berhubung dan membolehkan mereka berkumpul untuk menyemarakkan lagi aktiviti kebudayaan dan warisan, maka sebuah galeri diwujudkan (Persatuan Peranakan Cina Kelantan 2019).

Penubuhan galeri ini diasaskan hasil mesyuarat Persatuan Peranakan Cina Kelantan (PPCK) pada tahun 2015 setelah penaung PPCK, Yeap Boon Yang bersetuju menyumbangkan rumah ini kepada PPCK untuk dijadikan galeri. Pembinaan galeri ini juga telah diasaskan oleh pensyarah dari Universiti Teknologi Mara (UTM) Dr. Lim Yong Long dan pensyarah Universiti Malaysia Kelantan (UMK) Dr. Wee Seng Kew. Selain itu, galeri ini juga dijadikan pusat penyelidikan bagi Pusat Kajian Alam Bina Dunia Melayu (KALAM), UTM. Sebelum berubah fungsi, galeri ini adalah rumah milik keluarga generasi ketiga bagi keluarga Yeap iaitu, Yeap Eng Beng. Kepentingan untuk memulihara dan memelihara rumah tradisional ini adalah kerana nilai-nilai warisan dan estetika seni bina yang terdapat padanya. Rumah ini dipercayai dibina pada sekitar 1895 dan siap sepenuhnya pada tahun 1934. Menurut waris keluarga Yeap yang juga Naib Pengerusi PPCK, Yeap Hing Chai rumah ini kemudiannya dipindahkan ke tapak baharu juga bertempat di Tanah Merah untuk dijadikan galeri Peranakan Cina Kelantan (PCK) (Persatuan Peranakan Cina Kelantan 2019).

Pemindahan ini membuktikan tahap penyertaan penglibatan komuniti setempat dalam menggunakan semula rumah ini berubah ke peringkat aktif. Kesedaran untuk menggunakannya semula menunjukkan komuniti Peranakan Cina di kawasan tersebut berupaya untuk memberi maklumat (informing) dan terlibat dalam khidmat rundingan (consultation) serta placation. Ubah suai rumah ini kepada galeri bukan sahaja melibatkan komuniti Peranakan Cina Kelantan di kawasan tersebut tetapi juga orang-orang Melayu di kawasan yang sama. Hal ini kerana, rumah ini mempunyai banyak pengaruh seni bina Melayu dan telah dibina dengan bantuan penduduk kampung yang terdiri daripada orang-orang Melayu. Pengaruh elemen seni bina Melayu dapat dilihat pada struktur rumah ini yang dapat dilihat pada lantai jarang, jemuran, berbumbung $\mathrm{V}$ 
terbalik dengan reka bentuk melengkung dan cerun serta lantai berpanggung atau lantai bertiang tinggi (Persatuan Peranakan Cina Kelantan 2019).

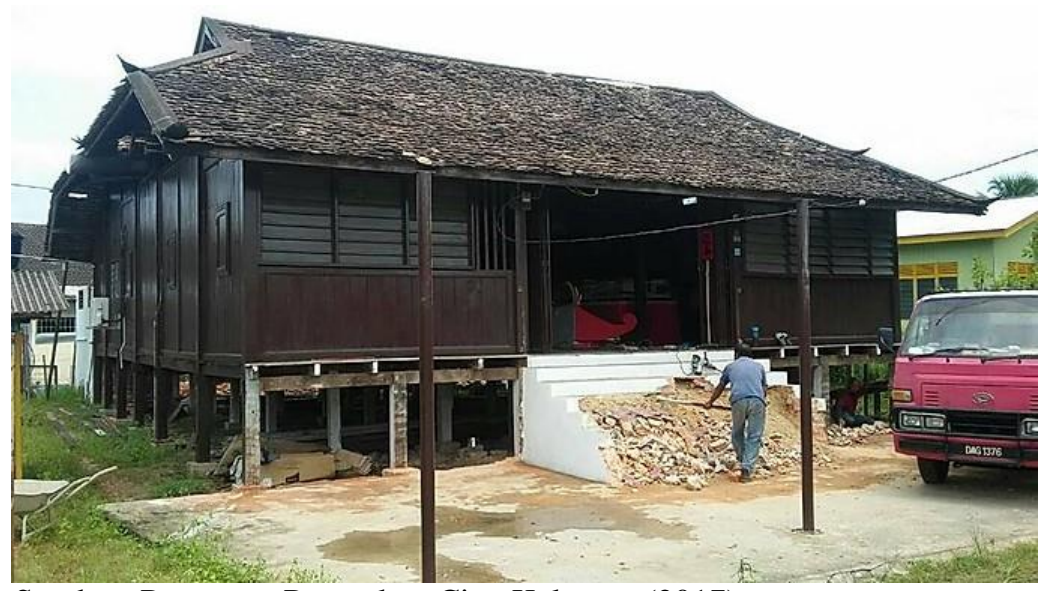

Sumber: Persatuan Peranakan Cina Kelantan (2017)

Rajah 2. Kerja-kerja merobohkan tangga bagi tujuan menyesuaikan fungsi baharu Galeri PCK.

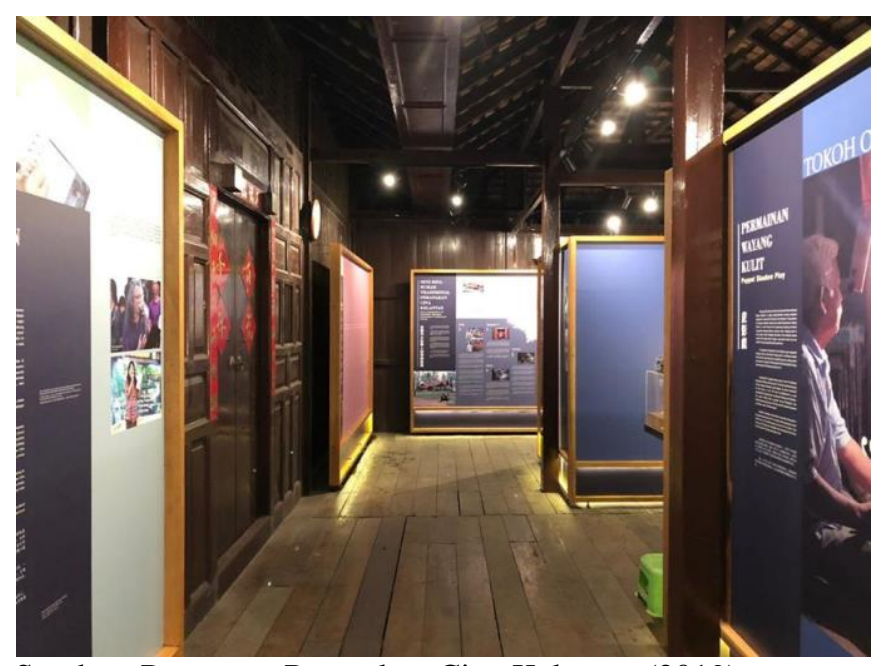

Sumber: Persatuan Peranakan Cina Kelantan (2019)

Rajah 3. Ruangan dalam Galeri PCK.

Sejak beroperasi pada 2019, telah banyak aktiviti dilakukan di galeri ini misalnya gotong royong, kunjungan hormat organisasi luar, mesyuarat agung, lokasi penggambaran dokumentari dan penyelidikan serta upacara Suat Mongkhon \& Thad Bhat sempena sambutan Tahun Baru Cina. Kini, Galeri PCK diletakkan di bawah naungan PPCK. Selain itu, bagi memastikan pemuliharaan dan pemeliharaannya dapat dilakukan dengan konsisten dan komprehensif, PPCK juga telah menjalin kerjasama teknikal dengan Universiti Teknologi Mara (UTM) pada tahun 2016. PPCK juga telah terlibat sama dalam projek penyelidikan daripada aspek sosiobudaya dengan Universiti Malaysia Kelantan (UMK) pada tahun 2018 sehingga kini. Secara tidak langsung, hal ini telah membuktikan tahap penyertaan komuniti setempat dalam pemuliharaan berubah kepada tahap aktif kerana mereka telah menjalin Kerjasama (partnership), mengagihkan 
kuasa (delegated power) dan mengawal atau mengendalikan komunitinya (citizen control) bagi tujuan melindungi rumah tradisional mereka daripada ancaman kepupusan.

Hasil analisis kajian dapat menyimpulkan, komuniti setempat telah melibatkan diri dengan proaktif dalam usaha melindungi bangunan bersejarah di kawasan mereka. Berdasarkan Kerangka Penyertaan Masyarakat (Ladder of participation) yang dikemukakan oleh Arnstein (1969), komuniti setempat terlibat aktif dalam menyesuaigunakan semula bangunan bersejarah di kedua-dua kawasan kajian. Mereka mempunyai kawalan dan kekuatan untuk mengawal (citizen control), mengagihkan kuasa (delegated power) dan bekerjasama (partnership) bukan sahaja sesama mereka tetapi juga dengan agensi lain. Perbincangan ini dijelaskan seperti jadual berikut:

Jadual 1. Penglibatan komuniti setempat di kawasan kajian berdasarkan tahap penyertaan masyarakat Arnstein (1969).

\begin{tabular}{|c|c|c|c|}
\hline Item & Tahap penyertaan & $\begin{array}{l}\text { Masjid Lama } \\
\text { Kedai Mulong }\end{array}$ & $\begin{array}{l}\text { Galeri } \\
\text { PPCK }\end{array}$ \\
\hline Penglibatan komuniti setempat: & citizen control & & \\
\hline i. Pemuliharaan & delegated power & / & / \\
\hline ii. Kesedaran dan pemahaman & partnership & I & / \\
\hline iii. Rekod dan dokumentasi & placation & I & I \\
\hline iv. Pengurusan dan pemantauan & consultation & I & I \\
\hline $\begin{array}{l}\text { Implementasi pemuliharaan bangunan } \\
\text { bersejarah: }\end{array}$ & $\begin{array}{l}\text { informing } \\
\text { therapy }\end{array}$ & & \\
\hline i. Penyesuaigunaan semula & manipulation & I & I \\
\hline ii. Kerjasama agensi luar & & I & I \\
\hline \multicolumn{4}{|l|}{ Impak: } \\
\hline i. Pelancongan warisan & & I & / \\
\hline ii. Penjanaan ekonomi setempat & & I & I \\
\hline iii. Pembangunan infrastruktur & & I & I \\
\hline Kemapanan alam sekitar & & I & I \\
\hline
\end{tabular}

Oleh itu, hasil analisis berpandukan Kerangka Tangga Penyertaan Masyarakat yang dikemukakan oleh Arnstein (1969) menemukan, penglibatan komuniti setempat meningkat pada permulaan dari pasif kepada tahap aktif. Kesedaran untuk melindungi aset warisan yang wujud dalam kalangan komuniti setempat terbentuk setelah mereka diberi pemahaman yang jelas oleh pihak bertanggungjawab mengenainya. Maka, mereka akan bertindak untuk melindungi bangunan bersejarah dan juga dirujuk oleh pihak bertanggungjawab sepanjang proses pemuliharaan kerana komuniti setempat adalah kelompok yang mempunyai banyak maklumat. komuniti setempat di kawasan kajian telah membuktikan kekuatan mereka untuk bersama-sama melindungi aset warisan mereka. Justeru, pada peringkat ini komuniti setempat berupaya untuk terlibat sama dalam rundingan dan khidmat nasihat. Pada akhirnya, tahap penyertaan mereka berubah kepada penyertaan aktif sehingga mempunyai kekuatan untuk mempengaruhi ahli komuniti untuk bersama-sama terlibat dalam menggunakan semula bangunan bersejarah di kawasan mereka. Penglibatan mereka bukan sahaja dalam proses pemuliharaan tetapi juga perancangan jangka panjang yang membolehkan mereka menikmati manfaat daripada projek pemuliharaan tersebut. 


\section{Kesimpulan}

Kecenderungan dan kesukarelaan komuniti melibatkan diri dalam usaha melindungi sesebuah objek warisan menunjukkan bahawa mereka memahami tujuan, bersedia untuk membangun dan memajukan komunitinya. Walau bagaimanapun, kesediaan komuniti setempat dalam pemuliharaan warisan memerlukan pemahaman yang komprehensif agar objektif pendekatan ini dapat dicapai dengan optimum. Selain itu, komuniti setempat juga berpeluang menikmati manfaat hasil pemuliharaan warisan yang dilakukan bersama-sama pihak bertanggungjawab menerusi pendekatan bawah-atas (bottom-up approach). Berdasarkan kajian ini dapat dibuktikan komuniti setempat mempunyai pemahaman dan kesedaran yang tinggi untuk terlibat sama dalam memulihara dan memelihara warisan yang terdapat di kawasan mereka. Penduduk Kampung Masjid Lama Kedai Mulong secara sukarela melibatkan diri dalam memulihara balairung seri untuk digunakan semula sebagai masjid. Manakala komuniti Cina Peranakan di Tanah Merah menerusi Persatuan Peranakan Cina Kelantan juga terlibat dalam menyesuaigunakan semula rumah tradisional masyarakat Peranakan Cina sebagai galeri. Kajian ini juga menemukan komuniti setempat telah berpeluang menikmati manfaat hasil turut serta dalam menyesuaigunakan semula bangunan bersejarah di kawasan mereka. Masjid Lama Kedai Mulong dan Galeri PPCK merupakan antara produk yang menarik perhatian pelancong yang berkunjung di Kelantan. Justeru, komuniti setempat berpeluang menjana ekonomi dengan mengusahakan kedai makan dan kedai serbaneka berhampiran lokasi serta menjadi pemandu pelancong. Secara tidak langsung, penglibatan komuniti setempat dalam pemuliharaan bangunan-bangunan bersejarah ini dilihat sedikit sebanyak membantu kerajaan negeri bagi melonjakkan lagi pelancongan warisan di Kelantan.

\section{Rujukan}

A. Ghafar Ahmad. (2010). Siri syarahan umum pelantikan profesor: Pemuliharaan bangunan warisan di Malaysia: Pengalaman dan cabaran masa hadapan. Pulau Pinang, Penerbit Universiti Sains Malaysia.

Arnstein, S. (1969). A ladder of citizen participation. Journal of the American Institute of Planners, 35(4), 216-224.

Bullen, P.A., \& Love, P.E.D. (2011). Adaptive reuse of heritage buildings. Structural Survey, 29(5), 411-421.

Conejos, S., Langston, C., \& Smith, J. (2015). Enhancing sustainability through designing for adaptive reuse from the outset: A comparison of adaptSTAR and Adaptive Reuse Potential (ARP) models. Facilities, 33(9/10), 531-552.

Douglas, J. (2002). Building Adaptation. Woburn, Butterworth-Heinemann.

English Heritage. (2013). Heritage works: the use of historic buildings in regeneration. A toolkit of good practice". www.english-heritage.org.uk/publications/heritage-works/heritageworks-2013.pdf

Esther H.K. Yung, \& Edwin H.W. Chan. (2011). Problem issues of public participation in builtheritage conservation: Two controversial cases in Hong Kong. Habitat International, 35, 457-466. 
Haliza Abdul Rahman. (2010). Penglibatan masyarakat peribumi dalam isu berkaitan persekitaran: Tinjauan terhadap suku Mah Meri di Pulau Carey, Kuala Langat, Selangor. Kemanusiaan, 17, 111-134.

Jabatan Warisan Negara (JWN). (2009). Laporan akhir: Projek pemuliharaan Masjid Mulong, Kelantan. Kuala Lumpur, Jabatan Warisan Negara.

Jabatan Warisan Negara (JWN). (2009). Warisan kebangsaan. Kuala Lumpur, Jabatan Warisan Negara.

Kamarul Syahril Kamal, A. Ghafar Ahmad, \& Lilawati Ab. Wahab. (2007). Kecacatan bangunan dan kepentingan pemuliharaan warisan di bandaraya Ipoh. Prosiding National Conference on Malaysia Cityscape, 28-29 November, Lumut, Perak.

Lilawati Ab Wahab, A. Ghafar Ahmad, \& Badaruddin Mohamed. (2008). Pemuliharaan dan penyesuaigunaan semula bangunan bersejarah bagi menyokong industri pelancongan warisan negara. Prosiding Seminar Penyelidikan Siswazah Alam Bina, Fakulti Seni bina, Perancangan dan Ukur, Universiti Teknologi Mara, Kampus Seri Iskandar, Perak, hlm. 503-510.

Mohamad Khairul Anuar Ghazali, Yazid Saleh, \& Hanifah Mahat. (2021). Pembinaan kerangka konstruk kelestarian bandar warisan di Malaysia. Geografia-Malaysian Journal of Society and Space, 17(1), 211-226.

Mohd Jaki Mamat. (2014). Penglibatan masyarakat dalam pemuliharaan kawasan warisan di Pusat Bandaraya Ipoh, Perak, (Tesis Doktor Falsafah). Universiti Sains Malaysia.

Persatuan Peranakan Cina Kelantan. (2019). https://ppckelantan.wixsite.com

Plested, B.A., Edwards, R.W., \& Jumper-Thurman, P. (2007). Disparities in community readiness for HIV/AIDS prevention. Substance Use \& Misuse, 42(4), 729-739.

Rina Ilyana Zainal. (2007). Meninjau penglibatan penduduk tempatan dalam aktiviti pelancongan. Kajian kes: Kampung Serkat, Pontian, Johor, (Tesis Sarjana). Universiti Teknologi Malaysia.

Sabzali Musa Kahn, Effendi Shamsuddin, \& Nik Nairan Abdullah. (2011). Mendepani seni warisan dan kreatif dalam mencapai satu gagasan Melayu di Nusantara. Kertas kerja seminar Universiti Islam Negeri Sunan, Gunung Djati, Bandung.

Saiful Fazli Ramli. (2011). Adaptive reuse for historical buildings in Malaysia. A case study: Bukit Kepong Police Station, Malaysia, (Master thesis). University of Portsmouth.

Shen, L., \& Langston, C. (2010). Adaptive reuse potential. Facilities, 28(1/2), 6-16.

Solihah Mustafa, Mazdi Marzuki, Ruzanna Syamimi Ramli, Jabil Mapjabil, Mohammad Kadir Zainal Abidin, \& Mohamad Pirdaus Yusoh. (2015). Pengurusan bandar warisan UNESCO dan penglibatan komuniti tempatan: Kajian kes di George Town, Pulau Pinang. Geografia-Malaysian Journal of Society and Space, 11(2), 87-99.

Syed Zainol Abidin Idid. (1995). Pemeliharaan warisan rupa bandar: Panduan mengenali warisan rupa bandar berasaskan inventori bangunan warisan Malaysia. Kuala Lumpur, Badan Warisan Malaysia.

Teuku Afrizal \& Abdul Rahman Embong. (2013). Komuniti dan pengurusan persekitaran: Beberapa pengalaman Malaysia, Bangladesh, Zambia dan Vietnam. Kajian Malaysia, $31(2), 65-86$.

Tosun, C. (2000). Limit to community participation in the tourism development process in developing countries. Tourism Management, 21, 613-633.

Yazid Saleh. (2010). Pengenalan pemuliharaan bandar. Kuala Lumpur, Dewan Bahasa dan Pustaka. 